\title{
POTENSI DAUN SALAM (Syzigium polyanthum Walp.) \\ DAN BIJI JINTEN HITAM (Nigella Sativa Linn) SEBAGAI KANDIDAT OBAT HERBAL TERSTANDAR ASAM URAT
}

\author{
THE POTENTIAL OF SALAM LEAVES (Syzigium polyanthum Walp.) \\ AND BLACK CUMIN SEED (Nigella sativa Linn) AS A CANDIDATE STANDARIZED HERBAL \\ MEDICINE OF URIC ACID
}

\author{
Muhtadi*, Andi Suhendi, Nurcahyanti W., dan EM. Sutrisna \\ Fakultas Farmasi, Universitas Muhammadiyah Surakarta \\ pmuhtadi@gmail.com
}

\begin{abstract}
ABSTRAK
Pengujian aktivitas antihiperurisemia secara in vivo dari ekstrak tunggal dan kombinasi ekstrak serta standarisasi ekstrak dari daun Salam (Syzigium polyanthum Walp) dan biji Jinten Hitam (Nigella sativa Linn) telah dilakukan. Ekstraksi daun Salam dan Jinten Hitam dilakukan metode infundasi. Ekstrak dari masing-masing bahan, diuji antihiperurisemia secara in vivo terhadap mencit putih jantan galur Balb-C yang diinduksi dengan potasium oksonat dosis $250 \mathrm{mg} / \mathrm{kgBB}$. Kadar asam urat setelah pemberian ekstrak tunggal daun Salam dan Jinten Hitam dosis $200 \mathrm{mg} / \mathrm{kgBB}$ masing-masing adalah sebesar 0,640 dan 1,20 $\mathrm{mg} / \mathrm{dL}$. Sedangkan kombinasi ekstrak daun Salam-Jinten Hitam adalah sebesar 0,840 mg/dL. Ekstrak Secara keseluruhan berdasarkan hasil pemeriksaan standar umum ekstrak tumbuhan obat, kedua bahan yang diteliti telah memenuhi persyaratan yang dipersyaratkan oleh Badan POM RI
\end{abstract}

Kata kunci : Syzigium polyanthum Walp, Nigella sativa Linn, antihiperurisemia, standarisasi ekstrak

\section{ABSTRACT}

Determination of antihyperuricemia in vivo activity from a single and combination of aqueous extracts, also standardization of extracts Salam leaves (Syzigium polyanthum Walp) and Nigella sativa Linn seed has been performed. Antihiperuricemia activity performed on male white mice Balb-C strain induced by potassium oxonate with dose of $250 \mathrm{mg} / \mathrm{kg} \mathrm{BW}$. Uric acid content in blood serum after oral administrations single extract of Salam and black cumin with a dose of $200 \mathrm{mg} / \mathrm{kg} \mathrm{BW}$ were 0.640 and $1.20 \mathrm{mg} / \mathrm{dL}$, respectively. While the combination of extracts uric acid level was $0.840 \mathrm{mg} / \mathrm{dL}$. Overall parameters on general standard of medicinal plant extracts, both materials under study have met the NFDA requirements.

Keywords: Syzigium polyanthum Walp., Nigella sativa Linn, antihyperuricemia, standardized extract

\section{PENDAHULUAN}

Indonesia merupakan salah satu negara mega diversity untuk tumbuhan obat di dunia. Wilayah hutan tropika Indonesia memiliki keanekaragaman hayati tertinggi ke-2 di dunia setelah Brasil. Dari 40.000 jenis flora yang ada di dunia sebanyak 30.000 jenis dijumpai di Indonesia dan 940 jenis di antaranya diketahui berkhasiat sebagai obat yang telah dipergunakan dalam pengobatan tradisional secara turun-temurun oleh berbagai etnis di Indonesia. Jumlah tumbuhan obat tersebut meliputi sekitar $90 \%$ dari jumlah tumbuhan obat yang terdapat di kawasan Asia (Puslitbangtri, 1992).

Menurut Badan POM (1991) ada 283 spesies tumbuhan obat yang sudah terdaftar digunakan oleh industri Obat Tradisional di Indonesia, di antaranya 180 spesies tumbuhan obat yang berasal dari hutan tropika. Kekayaan alam Indonesia telah terbukti mampu menghidupi masyarakat penghuninya. Masyarakat lokal memiliki pengertian yang dalam akan manfaat berbagai jenis tumbuhan lokal. Tidak kurang dari 400 etnis masyarakat Indonesia erat kehidupannya dengan alam dan memiliki pengetahuan tradisional yang tinggi dalam memanfaatkan tumbuhan obat untuk perawatan kesehatan. Diantaranya, yang mayoritas menggunakan tumbuhan obat untuk penyembuhan berbagai macam penyakit seperti malaria, diare, demam, sakit perut, dan sakit kuning yaitu etnis Sunda yang diketahui telah memanfatkan 305 jenis tumbuhan, etnis Jawa memanfaatkan 114 jenis tumbuhan, etnis Melayu mengenal 131 jenis tumbuhan, dan etnis Bali mengenal 105 jenis tumbuhan (Darusman et al, 2004).

Penyakit asam urat adalah jenis artritis yang sangat menyakitkan yang disebabkan oleh penumpukan kristal pada persendian, akibat tingginya kadar asam urat di dalam tubuh. Sendisendi yang seringkali diserang terutama adalah jarijari kaki, dengkul, tumit, pergelangan tangan, jari tangan dan siku. Selain nyeri, penyakit asam urat juga dapat membuat persendian membengkak, meradang, panas dan kaku. Sekitar $90 \%$ penyakit 
asam urat disebabkan oleh ketidakmampuan ginjal membuang asam urat secara tuntas dari tubuh melalui air seni. Sebagian kecil lainnya karena tubuh memproduksi asam urat secara berlebihan. Penyakit asam urat kebanyakan diderita oleh pria di atas 40 tahun dan wanita yang telah menopause. Penderita asam urat biasanya juga memiliki keluhan lain seperti tekanan darah tinggi, penyakit ginjal, diabetes dan aterosklerosis. Separuh dari penderita asam urat adalah orang yang kegemukan. Bila dibiarkan, penyakit asam urat bisa berkembang menjadi batu ginjal dan mengakibatkan gagal ginja (Martin, 1987)

Hasil penelitian pendahuluan, terbukti bahwa dekokta daun salam pada dosis $1,25 \mathrm{~g} / \mathrm{kg} \mathrm{BB}$ mampu menurunkan kadar asam urat dalam darah mencit putih jantan secara efektif (Handadari, 2007) dan infusa daun Salam pada dosis 2,5 g/kg BB mampu menurunkan kadar asam urat yang setara dengan allopurinol dosis $10 \mathrm{mg} / \mathrm{kg}$ BB (Ariyanti, 2007). Aktivitas biologis jinten hitam yang diantaranya adalah antiinflamasi (Subijanto \& Diding, 2008), antioxidan (Thippeswamy and Naidu, 2005), menurunkan kadar kalsium oksalat dalam urin (Hadjzadeh et al, 2007), dan antiartritis (El Dakhakhny et al, 2006).

Penggunaan obat tradisional (jamu) di Indonesia pada hakekatnya merupakan bagian kebudayaan bangsa Indonesia. Keuntungan dari penggunaan obat tradisional pada prinsipnya adalah efek samping yang relatif kecil dibandingkan obat modern. Meskipun secara empiris obat tradisional mampu menyembuhkan berbagai macam penyakit, tetapi khasiat dan kemampuannya belum banyak dibuktikan secara ilmiah maupun klinis. Selain itu, belum banyak diketahui senyawa kimia apa yang bertanggung jawab terhadap khasiat obat tradisional tersebut (Wijayakusuma, 2002).

Salah satu tanaman yang banyak digunakan dalam pengobatan tradisional adalah Jinten Hitam yang memiliki kandungan kimia yang kurang lebih sama dengan salam meskipun belum ada penelitian tentang aktivitas penurunan terhadap kadar asam urat darah mencit putih. Oleh karena itu, perlu dilakukan penelitian untuk mengetahui aktivitas ekstrak Jinten Hitam dalam menurunkan kadar asam urat darah mencit putih dan juga penelitian lanjutan untuk mengungkapkan ekstrak daun salam dan Jinten Hitam sebagai obat herbal terstandar (OHT) khususnya dalam pengobatan asam urat, dengan mengikuti metodologi penelitian yang direkomendasi oleh BPOM RI.

\section{BAHAN DAN METODE}

\section{Uji Praklinis}

Bahan: Ekstrak air daun salam dan biji Jinten hitam, Potasium oksonat p.a (Aldrich Chemical Company), Allopurinol p.a (Sigma), $\mathrm{NaCl} 0,9 \%$, Aquadest dan reagen kit uric acid FS*TBHBA (DyaSys).
Hewan percobaan: mencit putih jantan galur BalbC dengan berat badan rata-rata 30-40 gram dan berumur 2-3 bulan.

\section{Standarisasi Ekstrak}

Bahan: Ekstrak air daun salam dan Biji Jinten hitam, toluen p.a, n-heksana p.a, etil asetat p.a, aseton p.a etanol p.a, kloroform p.a (merck), $\mathrm{HNO}_{3}$ pekat (merck), $\mathrm{HClO}_{4}$ (merck), $\mathrm{HCl} 2 \mathrm{~N}, \mathrm{H}_{2} \mathrm{SO}_{4}$ encer, folin ciocalteu (merck), $\mathrm{Na}_{2} \mathrm{CO}_{3} 7 \%, \mathrm{AlCl}_{3}$ $10 \%$, Kalium Asetat $1 \mathrm{M}$, aqua destilata, aqua bidestilata (Ikapharmindo), kertas saring (Sartorius), larutan $\mathrm{Pb}$ dan $\mathrm{Cd}$ standar 1000 ppm (merck), baku aflatoksin campuran (B1,B2,G1 dan G2) (Sigma Chemical Company), asam galat p.a ( Sigma), Quercetin p.a (sigma), plat silika gel GF254 (merck),

\section{Metode Ekstraksi}

Ekstraksi dilakukan dengan cara serbuk daun salam atau Jinten Hitam direbus dengan air sampai volume menjadi separoh dari volume awal, kemudian disaring dan filtrat dievaporasi dengan rotary evaporator (RE) sehingga diperoleh ekstrak kental. Kemudian ekstrak kental yang diperoleh dikeringkan dalam Vaccum Dryer dan Vaccum Oven sampai kering.

\section{Uji Praklinis}

1. Pembuatan Hiperurisemia

Kadar asam urat tinggi (hiperurisemia) dibuat dengan cara menginjeksikan secara intraperitonial potasium oksonat $250 \mathrm{mg} / \mathrm{kg} \mathrm{BB}$ atau $5 \mathrm{mg} / 20 \mathrm{~g} \mathrm{BB}$ pada mencit (Zhao et al., 2005).

2. Uji Pendahuluan Praklinis

Uji pendahuluan ini dilakukan untuk tujuan mendapatkan data tentang dosis ekstrak, waktu pengambilan darah, dan ekstrak tunggal yang aktif dalam menurunkan kadar asam urat.

3. Perlakuan pada Hewan Uji

Hewan uji dibagi menjadi beberapa kelompok perlakuan, yaitu meliputi: kelompok kontrol negatif / hiperurisemia (potassium oksonat dosis $250 \mathrm{mg} / \mathrm{kgBB}$ ), kontrol positif (allopurinol dosis $10 \mathrm{mg} / \mathrm{kgBB}$ ), ekstrak air daun salam dan Jinten Hitam dosis tunggal $(200 \mathrm{mg} / \mathrm{kgBB})$. Pemberian sediaan uji dilakukan satu jam setelah induksi hiperurisemia (potassium oksonat dosis 250 $\mathrm{mg} / \mathrm{kgBB}$ )

4. Pengambilan Darah

Pengambilan darah dilakukan dua jam setelah induksi hiperurisemia (potassium oksonat dosis $250 \mathrm{mg} / \mathrm{kgBB}$ ), darah diambil lewat mata mencit melalui cabang vena opthalmicus yang terletak pada saccus medianus orbitales dengan pipa kapiler. Darah ditampung dalam tabung ependorf, setelah darah menggumpal disentrifus sehingga didapatkan serum.

5. Penetapan Kadar Asam Urat 
Kadar asam urat ditetapkan berdasarkan reaksi enzimatik menggunakan reagen uric acid $\mathrm{FS}^{*}$ TBHBA. Serum darah yang telah dicampur homogen dengan pereaksi uric acid FS* TBHBA diinkubasi selama 10 menit pada suhu $37^{\circ} \mathrm{C}$. Selanjutnya larutan sampel, standart dan blangko dibaca absorbansinya dengan menggunakan spektrofotometer StartDust FC*15 pada panjang gelombang $546 \mathrm{~nm}$.

\section{Standarisasi Ekstrak}

Standarisasi ekstrak (bahan) mengikuti prosedur baku berdasarkan Materia Medika Indonesia dan Parameter Standar Umum Ekstrak Tumbuhan Obat yang direkomendasikan oleh BPOM RI, meliputi parameter spesifik dan non spesifik.

\section{Parameter spesifik:}

1. Penetapan kadar senyawa larut air.

Sebanyak 1,0 g ekstrak direndam 25,0 mL airkloroform LP selama 24 jam, disaring. Kemudian filtrat diuapkan, residu dipanaskan pada suhu $105^{\circ} \mathrm{C}$ hingga bobot tetap. Kadar sari larut air dihitung dalam persen terhadap ekstrak awal.

2. Penetapan kadar kandungan total kimia (Chang et al, 2002)

a. Kadar kandungan flavonoid total

Penetapan kandungan total flavonoid dilakukan secara kolorimetri dengan spektrofotometri visibel. Kurva kalibrasi quercetin dibuat dengan seri kadar $4 ; 6 ; 8$; $10 ; 12 ; 14 \mu \mathrm{g} / \mathrm{ml}$. Absorbansi larutan standar dibaca pada spektrofotometer yang sebelumnya direaksikan dengan $0,1 \mathrm{ml}$ alumunium klorida $10 \%$ dan $0,1 \mathrm{ml}$ kalium asetat $1 \mathrm{M}$. Inkubasi dilakukan pada ruang gelap selama 85 menit pada suhu kamar, absorbansi diukur pada panjang gelombang $437 \mathrm{~nm}$.

b. Kadar kandungan fenolat total

Penetapan kadar fenolik total dihitung sebagai Gallic Acid Equivalent (\%). Kurva kalibrasi dibuat dengan menggunakan seri konsentrasi 2, 4, 6, 8, dan $10 \mu \mathrm{g} / \mathrm{ml}$. Reagen yang dipakai adalah folin ciocalteu. Absorbansi diukur pada panjang gelombang maksimum $745 \quad \mathrm{~nm}$ dengan spektrofotometer.

\section{Parameter non spesifik (Anonim, 2000)}

1. Penetapan bobot penyusutan

Lebih kurang timbang 2,0 g ekstrak dalam botol timbang dangkal bertutup yang sebelumnya telah dipanaskan pada suhu $105{ }^{\circ} \mathrm{C}$ selama 30 menit dan hingga bobot tetap.

2. Penetepan kadar air

Penetapan kadar air ditetapkan dengan cara distilasi toluene. Labu dipanaskan hati-hati selama 15 menit, setelah toluene mulai mendidih, penyulingan diatur 2 tetes/detik, lalu 4 tetes/detik. Setelah semua toluene mendidih. Setelah lapisan air dan toluene memisah sempurna, volume air dibaca dan dihitung kadar air dalam persen terhadap berat ekstrak semula.

3. Penetapan kadar abu total

Lebih kurang 2,0 g ekstrak ditimbang seksama dimasukkan ke dalam krus silikat yang telah dipijarkan, hingga bobot tetap dan ditimbang.

4. Penetapan kadar abu tidak larut asam

Hitung kadar abu yang tidak larut dalam asam terhadap bahan yang telah dikeringkan.

5. Penetapan cemaran aflatoksin

Menggunakan metode KLT (Kromatografi Lapis Tipis) dengan membandingkan baku aflatoksin campuran.

6. Penetapan kadar cemaran logam berat $(\mathrm{Pb}$ dan Cd)

Dengan metode digesti basah menggunakan asam nitrat dan asam perklorat sebagai katalisator. Kadar $\mathrm{Pb}$ dan $\mathrm{Cd}$ dibaca dengan metode spektrofotometri Serapan Atom.

Uji Kandungan Kimia Ekstrak (Depkes RI, 1978)

1. Uji Pendahuluan

a. Uji alkaloid

Reaksi Meyer dan Bouchardat

b. Uji Fenolik

c. Uji Flavonoid (Uji Taubeck)

2. Profil KLT

Larutan $10 \%$ ekstrak dalam aseton di KLT menggunakan fase diam: silika gel $\mathrm{GF}_{254}$ dengan dielusi fase gerak: n-heksana : etil asetat ( $9: 1)$, deteksi dengan lampu UV 254 $\mathrm{nm}$ dan $366 \mathrm{~nm}$.

Masing-masing analisis parameter tersebut, mengikuti prosedur yang telah disarankan oleh BPOM RI.

\section{HASIL DAN PEMBAHASAN \\ Hasil Uji Pendahuluan}

Uji pendahuluan dilakukan untuk mengetahui bagaimana model hiperurisemia pada mencit putih jantan, yaitu dengan mencari dosis efektif potasium oksonat dalam menaikkan kadar asam urat dari kondisi normal.

\begin{tabular}{llll}
\multicolumn{4}{l}{ Tabel 1- Data uji pendahuluan pembuatan model hiperurisemia } \\
\hline Perlakuan & $\begin{array}{l}\text { Kadar Asam } \\
\text { Urat (mg/dL) }\end{array}$ & Rata-rata & SD \\
\hline Kontrol normal & 1.3 & 1.433 & 0.231 \\
$\begin{array}{l}\text { Tanpa } \\
\text { Perlakuan) }\end{array}$ & 1.7 & & \\
\hline Potasium & 1.3 & & \\
oksonat & 3.1 & 3.067 & 0.950 \\
Dosis 250 & 4 & & \\
mg/kgBB & 2.1 & & \\
\hline
\end{tabular}

Mencit dikatakan hiperurisemia jika kadar asam urat darahnya berkisar antara 1,7-3,0 mg/ dL. 
Hasil uji pendahuluan tersebut menunjukkan bahwa dengan potassium dosis $250 \mathrm{mg} / \mathrm{kg} \mathrm{BB}$ telah mampu menaikkan kadar asam urat mencit yaitu dari kadar normal dengan rata-rata $1,433 \mathrm{mg} / \mathrm{dL}$ menjadi 3,067 $\mathrm{mg} / \mathrm{kg}$ BB. Secara statistik kadar asam urat kelompok kontrol dan kelompok potassium oksonat sangat berbeda signifikan yaitu dengan nilai signifikansi sebesar 0,205 ( $\mathrm{p}>0,05)$.

\section{Hasil Uji Praklinik dari Ekstrak}

Hewan uji yang digunakan pada penelitian ini adalah mencit putih jantan (Mus muculus) yang memiliki enzim urikase yang dapat memecah asam urat dengan membentuk produk akhir allantoin yang bersifat mudah larut dalam air (Martin, 1987). Untuk memperkecil variasi biologis, maka peneliti melakukan pengendalian terhadap beberapa variabel antara lain dengan cara menggunakan hewan uji yang kurang lebih sama variasi biologisnya yaitu diantaranya dengan berat badan sekitar $30-40$ gram, umur 2-3 bulan, galur Balb-C, jenis kelamin jantan dan diperlakukan sama yaitu ditempatkan dalam kandang dengan jumlah tiap kandangnya sama dan diberi makanan yang sama serta sebelum diberi perlakuan hewan uji dipuasakan terlebih dahulu selama \pm 2 jam dengan tetap diberi minum ad libitum. Hal ini dilakukan agar kondisi hewan uji sama dan untuk mengurangi pengaruh makanan yang dikonsumsi terhadap sediaan uji yang diberikan dalam penelitian. Dan untuk mengurangi tingkat kestresan hewan uji diadaptasikan dengan kondisi laboratorium selama 7 hari.

Pemilihan jenis kelamin jantan lebih didasarkan pada pertimbangan bahwa mencit jantan tidak mempunyai hormone estrogen, jikalaupun ada hanya dalam jumlah yang relative sedikit serta kondisi hormonal pada jantan lebih stabil jika dibandingkan dengan mencit betina karena pada mencit betina mengalami perubahan hormonal pada masa-masa tertentu seperti pada masa siklus estrus, masa kehamilan dan menyusui dimana kondisi tersebut dapat mempengaruhi kondisi psikologis hewan uji tersebut. Selain itu tingkat stress pada mencit betina lebih tinggi dibandingkan dengan mencit jantan yang mungkin dapat mengganggu pada saat pengujian.

Potasium oksonat digunakan sebagai induktor hiperurisemia karena potasium oksonat merupakan inhibitor urikase yang kompetitif untuk meningkatkan kadar asam urat dengan jalan mencegah perubahan asam urat menjadi allantoin. Dimana allantoin bersifat larut air dan dapat diekskresi lewat urin, sehingga dengan dihambatnya enzim rikase oleh potassium oksonat maka asam urat akan tertumpuk dan tidak tereliminasi dalam bentuk urin.

Kontrol positif yang digunakan adalah allopurinol yaitu salah satu obat pirai atau gout yang sering digunakan dalam pengobatan. Allopurinol merupakan satu-satunya urikostatikum yang saat ini digunakan secara terapeutik, yang bekerja untuk mengurangi pembentukan asam urat. Sedangkan yang bekerja untuk meningkatkan eliminasi asam urat disebut urikosurika (Mutschler, 1991). Allopurinol merupakan substrat ksantin oksidase dan dieliminasi melalui ginjal terutama sebagai oksipurinol (sering juga disebut dengan istilah yang salah yaitu aloksantin) (Schunack et al, 1990). Allopurinol maupun oksipurinol, menghambat ksantin dan asam urat, dimana dalam dosis rendah mekanisme penghambatan berlangsung secara kompetitif dan dalam dosis tinggi bekerja secara tidak kompetitif. Allopurinol yang memiliki waktu paroh dalam plasma sekitar 40 menit, dihidrolisis oleh ksantin oksidase menjadi metabolit (Mutschler, 1991). Metabolit allopurinol-1-ribonukleotida, yang dapat dinyatakan kecil dalam ekstrak organ, mungkin bertanggung jawab untuk inhibisi tambahan dari sintesis de novo purin (Schunack et al, 1990). Melalui penghambatan ksantin oksidase maka hipoksantin dan ksantin diekskresi lebih banyak dalam urin sehingga kadar asam urat dalam darah dan urin menurun (Mutschler, 1991).

Sediaan uji yang digunakan untuk menurunkan kadar asam urat dalam penelitian ini adalah ekstrak air dari daun salam dan jinten hitam. Metode penyarian yang digunakan adalah ekstraksi dengan pelarut air, dimana metode tersebut mirip dengan penggunaan bahan nabati sebagai obat tradisional (jamu) yaitu dengan merebus bahan dan mengambil konsentratnya untuk diminum sehingga kesetaraan perlakuan secara tradisional dan perlakuan dalam penelitian identik. Bedanya dalam penelitian ini konsentrat yang diperoleh setelah perebusan diuapkan dalam vacuum dryer sampai tebentuk ekstrak kering.

Penetapan kadar asam urat ditetapkan dengan metode enzimatik dengan menggunakan reagen Uric acid FS*TBHBA (2,4,6-tribromo3hydroxybenzoic acid) dengan menggunakan alat spektrofotometer StarDust FC 15. Mekanisme yang terjadi adalah asam urat dioksidasi oleh enzim urikase dengan bantuan $\mathrm{H}_{2} \mathrm{O}$ dan $\mathrm{O}_{2}$ menjadi allantoin, karbondioksida dan hidrogen peroksida. Hidrogen peroksida yang terbentuk akan 
bereaksi dengan 4-aminoantipirin dan TBHBA menjadi kuinonimin yang berwarna merah muda dimana reaksi tersebut dikatalisis oleh enzim peroksidase (POD). Besarnya intensitas warna yang dihasilkan oleh kuinonimin tersebut ekuivalen dengan kadar asam urat dalam darah. Mekanisme reaksi tersebut dapat dilihat pada Gambar 1.

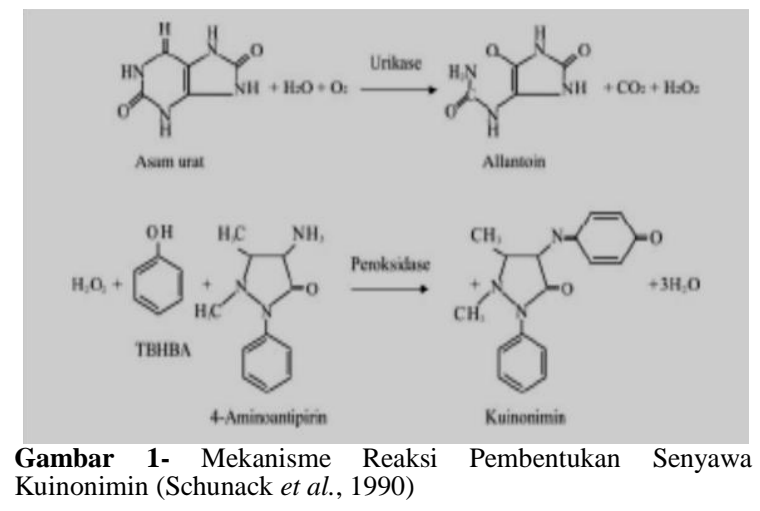

Data kadar asam urat dalam serum mencit setelah diinduksi dengan potasium oksonat dan pemberian sediaan uji ekstrak dosis tunggal 200 $\mathrm{mg} / \mathrm{kgBB}$ tersaji pada Tabel 2.

Tabel 2- Kadar Asam Urat Dalam Serum Setelah Perlakuan dengan Ekstrak dan Persen Penuruanannya

\begin{tabular}{lll}
\hline Kelompok Perlakuan & $\begin{array}{l}\text { Kadar Asam Urat }(\mathrm{n}=5) \pm \mathrm{SD} \\
\mathrm{mg} / \mathrm{dL}\end{array}$ & Persentase Penurunan $(\%)$ \\
\hline $\begin{array}{l}\text { Kontrol Negatif } \\
\text { Potasium Oksonat } 250 \mathrm{mg} / \mathrm{kgBB})\end{array}$ & $3,100 \pm 0,346^{*}$ & 93,55 \\
$\begin{array}{l}\text { Kontrol Positif } \\
\text { (Allopurinol } 10 \mathrm{mg} / \mathrm{kgBB})\end{array}$ & $0,200 \pm 0,100$ & 79,35 \\
$\begin{array}{l}\text { Ekstrak Daun Salam } \\
(200 \mathrm{mg} / \mathrm{kgBB})\end{array}$ & $0,640 \pm 0,167$ & 61,29 \\
$\begin{array}{l}\text { Ekstrak Biji Jinten hitam } \\
(200 \mathrm{mg} / \mathrm{kgBB})\end{array}$ & $1,200 \pm 0,561 *$ & 72,90 \\
$\begin{array}{l}\text { Ekstrak Salam - Jinten hitam } \\
(200 \mathrm{mg} / \mathrm{kgBB})\end{array}$ & $0,840 \pm 0,358 *$ & \\
\hline
\end{tabular}

keterangan $*$ : menunjukkan perbedaan signifikan terhadap kontrol positif $\mathrm{p}<0,05$

Berdasarkan Tabel 2. maka allopurinol, ekstrak daun salam, Jinten Hitam maupun kombinasi ekstrak salam dan Jinten Hitam mampu menurunkan kadar asam urat dalam darah mencit putih jantan galur Balb-C jika dibandingkan dengan kontrol negatif (Potasium oksonat). Hasil uji anova terhadap kadar asam urat dari kelompok hewan uji didapatkan bahwa kadar asam urat antara kontrol positif dengan kontrol positif, ekstrak jinten dan kombinasi ekstrak menununjukkan perbedaan signifikan. Namun kelompok perlakuan ekstrak daun salam menunjukkan perbedaan yang tidak signifikan, sehingga dapat dikatakan bahwa kemampuan menurunkan kadar asam urat antara alopurinol dengan ekstrak daun salam adalah sama.

Sedangkan setelah dikombinasikan ekstrak Salam-Jinten Hitam penurunan yang dihasilkan hampir sama dengan penurunan oleh ekstrak tunggal
Salam meskipun masih lebih rendah penurunan yang dihasilkan oleh ekstrak tunggal daun salam. Oleh karena itu dapat disimpulkan bahwa ekstrak Jinten Hitam kurang poten dalam menurunkan kadar asam urat darah mencit putih jantan jika dibandingkan dengan ekstrak tunggal daun salam.

\section{Hasil dan Pembahasan Uji Standarisasi Ekstrak}

Parameter standarisasi ekstrak yang dilakukan antara lain meliputi analisis non-spesifik yaitu analisis susut pengeringan, bobot jenis, kadar air, kadar abu, cemaran aflatoksin, cemaran logam berat, dan analisis spesifik yang meliputi identitas ekstrak, senyawa terlarut dalam pelarut tertentu, juga uji kandungan kimia ekstrak. Hasil uji standarisasi ekstrak daun salam selengkapnya dapat dilihat pada Tabel 3 .

Tabel 3- Hasil pengujian standarisasi ekstrak parameter non-spesifik

\begin{tabular}{|c|c|c|c|c|c|c|}
\hline \multirow[b]{2}{*}{ Ekstrak } & \multicolumn{6}{|c|}{ Parameter non-spesifik } \\
\hline & $\begin{array}{c}\text { Susut } \\
\text { pengeringan }\end{array}$ & Kadar air & Kadar abu & $\begin{array}{c}\text { Kadar abu tidak } \\
\text { larut asam }\end{array}$ & $\begin{array}{c}\text { Cemaran logam } \\
\text { berat }(\mu \mathrm{g} / \mathrm{kg})\end{array}$ & $\begin{array}{l}\text { Cemaran } \\
\text { aflatoksin }\end{array}$ \\
\hline Salam & 12,287 & 6,733 & 28,537 & 22,110 & $\begin{array}{ll}2,782 & (\mathrm{~Pb}) \\
\text { Ttd } & (\mathrm{Cd})\end{array}$ & ttd \\
\hline $\begin{array}{l}\text { Biji Jinten } \\
\text { hitam }\end{array}$ & 14,969 & 7,100 & 7,147 & 5,374 & $\begin{array}{ll}6,405 & (\mathrm{~Pb}) \\
0,0096 & (\mathrm{Cd})\end{array}$ & $\operatorname{ttd}$ \\
\hline
\end{tabular}

Keterangan: ttd: tidak terdeteksi

Tabel 4- Hasil pengujian standarisasi ekstrak parameter spesifik

\begin{tabular}{cccc}
\hline \multirow{2}{*}{ Ekstrak } & \multicolumn{3}{c}{ Parameter spesifik } \\
\cline { 2 - 4 } & Sari larut air & Fenolat total & Flavonoid total \\
\hline
\end{tabular}




\begin{tabular}{cccc}
\hline Salam & 64,656 & 1,083 & 0,196 \\
Biji Jinten hitam & 28,651 & 0,664 & 0,400 \\
\hline
\end{tabular}

\section{Senyawa Identitas}

Senyawa identitas $\quad$ : Fluoretin (Salam) dan Luteolin (Biji Jinten hitam)

Rumus bangun :<smiles>O=C(CCc1ccc(O)cc1)c1c(O)cc(O)cc1O</smiles>

Gambar 3- Rumus bangun dari Fluoretin
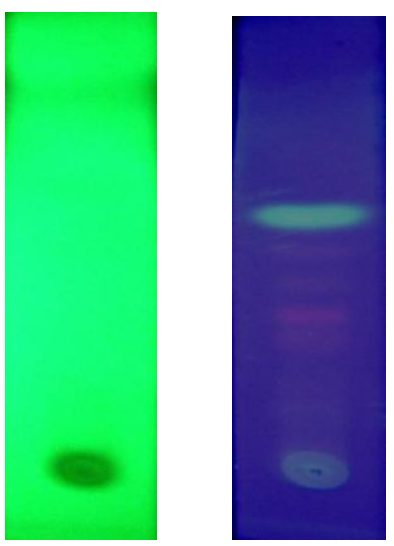

Gambar 5 - Profil KLT

\section{Pola Kromatogram KLT Ekstrak}

a. Ekstrak Daun Salam
Fase gerak
: n-Heksana - etil asetat (
$9: 1)$
Fase diam
elusi $5 \mathrm{~cm}$
Larutan uji
: Silika gel $\mathrm{GF}_{254}$, jarak
Volume penotolan
: $10 \%$ dalam aseton
Uji
S : Sampel ekstrak Daun Salam
Rf sampel 0,55 pada:
1. UV 254, pemadaman
2. UV 366, tampak berfluoresensi kuning

\section{b. Ekstrak Biji Jinten hitam}

$\begin{array}{ll}\begin{array}{l}\text { Fase gerak } \\ 9: 1)\end{array} & : \text { n-Heksana }- \text { etil asetat }( \\ \begin{array}{l}\text { Fase diam } \\ \text { elusi } 5 \mathrm{~cm}\end{array} & : \text { Silika gel } \mathrm{GF}_{254} \text {,jarak } \\ \text { Larutan uji } & : 10 \% \text { dalam aseton } \\ \text { Volume penotolan } & : \text { Totolkan } 20 \mu \mathrm{L} \text { Larutan } \\ \text { Uji } & \\ \mathrm{S} \quad \text { Sampel ekstrak Biji Jinten hitam } \\ \text { Rf sampel 0,76 pada: } \\ \begin{array}{l}\text { 1. UV 254, pemadaman }\end{array}\end{array}$<smiles>O=c1cc(-c2ccc(O)c(O)c2)oc2cc(O)cc(O)c12</smiles>

Gambar 4- Rumus bangun dari Luteolin
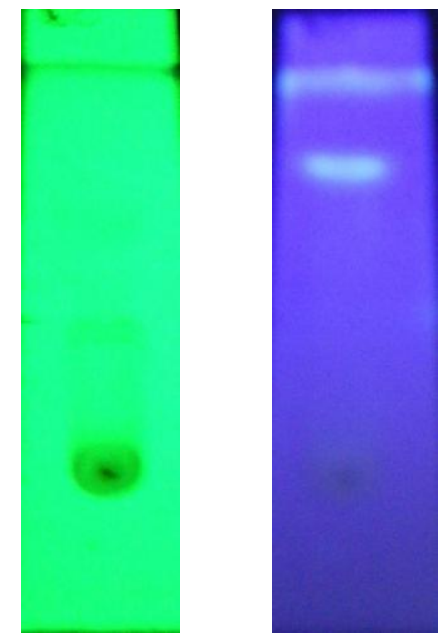

Gambar 6 - Profil KLT

2. UV 366, tampak berfluoresensi kuning

\section{KESIMPULAN}

1. Berdasarkan data uji praklinik antihiperurisemia, ekstrak daun Salam dan Jinten Hitam dan kombinasinya dengan dosis tunggal $200 \mathrm{mg} / \mathrm{kgBB}$ terbukti berpotensi menurunkan kadar asam urat dalam darah mencit putih jantan galur Balb-C yang dinduksi potassium oksonat dengan prosentase penurunan kadar asam urat berturut-turut adalah kurang lebih sebesar 79,35\%, 61,29\% dan $72,90 \%$. Sedangkan penurunan oleh allopurinol sebesar $93,55 \%$.

2. Hasil standarisasi ekstrak air daun salam adalah parameter kadar fenolat total dalam ekstrak daun Salam sebesar 1,083\% dan total flavonoid kadarnya sebesar 0,196\%. Dan hasil esktrak air Jinten Hitam kadar fenolat total sebesar 0,664\% dan kadar flavonoid total sebesar $0,400 \%$.

3. Senyawa identitas dari ekstrak daun salam adalah fluoretin sedangkan ekstrak Jinten Hitam adalah luteolin. Perbedaan senyawa aktif tersebutlah yang membedakan potensiasi 
penurunan kadar asam urat darah mencit putih jantan. Dari hasil yang diperoleh lebih poten senyawa fluoretin dari ekstrak daun salam.

\section{UCAPAN TERIMA KASIH}

Ucapan terima kasih disampaikan kepada DP2M Dikti yang telah memberikan bantuan dana penelitian RAPID tahun 2010, Rektor dan Pimpinan LPPM UMS yang memfasilitasi pelaksanaan dan penyelesaian penelitian, serta mitra UMKM CV. Almanar Herbafit yang bersedia bekerjasama dan memproduksi OHT hasil penelitian.

\section{DAFTAR PUSTAKA}

Anonim, 2000, Parameter Standar Umum Ekstrak Tumbuhan Obat, Dirjen POM Depkes RI, Jakarta.

Ariyanti, R., 2007, Pengaruh Pemberian Infusa Daun Salam (Eugenia polyantha Wight.)Terhadap Penurunan Kadar Asam Urat dalam Darah Mencit Putih Jantan hiperurisemia, Skripsi, Fakultas Farmasi Universitas Muhammadiyah Surakarta, Surakarta.

Chang, C., Yang, M., Wen, H., Chern, J., 2002, Estimation of Total Flavonoid Content in Propolis by Two Complementary Methods, Journal of Food and Drug Analysis, Vol. 10, No. 3, 178-182.

Departemen Kesehatan Republik Indonesia. 1978. Materia Medika Indonesia. Jilid 4. Jakarta. 109-111.

Hadjzadeh, M A R., Khoei, A., Hadzadeh, Z., Parizady, M., 2007, Ethanolic Extract of Nigella sativa L Seeds on Ethylene Glycol-Induced Kidney Calculi in Rats, Urology Journal, 4 (2),86-90

Handadari, H. R., 2007, Efek Decocta Daun Salam (Eugenia polyantha Wight.) Terhadap Penurunan Kadar Asam Urat dalam Darah Mencit Putih (Mus muculus) Jantan hiperurisemia, Skripsi, Fakultas Farmasi Universitas Muhammadiyah Surakarta, Surakarta.

El Dakhakhny, M., Darwish, I E., El Sakkar, M G., and Gumei, A A., 2006, Role of Nigella sativa Oil, Thymoquinone With and Without Pyrimethamine in Freund's Adjuvant Arthritis in Rat, Bull. Alex.Fac. med.,42(1), 191-197

Martin, D. W., 1987, Metabolisme Nukleotida Purin dan Pirimidin dalam Biokimia Harper, Edisi 20, diterjemahkan oleh Darmawan, Iyan, Penerbit Buku Kedokteran EGC, Jakarta.

Mutschler, E., 1991, Dinamika Obat, Buku Ajar Farmakologi dan Toksikologi, Edisi Kelima, ITB, Bandung, 217-221.

Schunack, W., Mayer, and K., Manfred, H., 1990, Senyawa Obat Kimia Farmasi, diterjemahkan oleh Joke, Witlmena dan Soebita, S., Gajah Mada University Press, Yogyakarta.

Subijanto, A A., \& Diding, H P., 2008, Pengaruh Minyak Biji Jinten Hitam (Nigella Sativa L.) terhadap Derajat Inflamasi Saluran Napas, Majalah Kedokteran Indonesia,58(6); 200-204

Thippeswamy, N B., \& Naidu, K A., 2005, Antioxidant potency of cumin varieties-cumin, black cumin and bitter cumin — on antioxidant systems, Eur Food Res Technol (220); 472-476

Wijayakusuma, H., 2002, Tumbuhan Berkhasiat Obat Indonesia Rempah, Rimpang dan Umbi. Prestasi Instan Indonesia, Jakarta. 